Araștırma Makalesi / Research Article

Bitki Koruma / Plant Protection
Iğdır Üniversitesi Fen Bilimleri Enstitüsü Dergisi, 9(3): 1212-1219, 2019

Journal of the Institute of Science and Technology, 9(3): 1212-1219, 2019

\title{
Detection of Viruses on Edible Seed Squash (Cucurbita pepo L.) in Yozgat Province, Turkey
}

\author{
Serkan YEŞí: ${ }^{1 *}$
}

\begin{abstract}
Cucurbits (Cucurbitaceae family) consist of 119 genera and 825 species and are cultivated worldwide, especially in tropical and subtropical regions. In the world, squash (Cucurbita pepo L.), watermelon (Citrullus lanatus (Thunb) Matsum\&Nakai), cucumber (Cucumis sativus L.), and melon (C. melo L.) are the most cultivated cucurbit species as vegetable crops. Squash is grown for fresh consuming, as well as its seeds are used like a snack in Turkey. Viruses are one of the most destructive pathogen groups on squash which is grown for seeds in Yozgat province. In this study, it was aimed to determine the virus infections in economically important squash planting fields in the province. Totally 140 plant samples which show widespread virus symptoms such as mottling, shoe-string, mosaic, stunting, curling, vine decline, distortion, and blistering were collected from plants in 2017. In this study, DAS-ELISA method is used for identifying the virus infections on the plant samples. According to the results of the DAS-ELISA $84.28 \%$ of plant samples were infected with Cucumber mosaic cucumovirus (CMV), Watermelon mosaic potyvirus (WMV), Papaya ring spot potyvirus-watermelon strain (PRSV-W), Zucchini yellow mosaic potyvirus (ZYMV), and Squash mosaic comovirus (SqMV). The prevalent virus was WMV with the ratio of $57.85 \%$. It was followed by ZYMV which was detected on the samples at the ratio of $53.57 \%$. Besides, double and multiple virus infections were determined commonly in the samples. Especially, ZYMV+WMV mixed infections were common. The infection of Cucumber green mottle mosaic tobamovirus (CGMMV) wasn't determined in the survey area.
\end{abstract}

Keywords: Yozgat, DAS-ELISA, Edible seed squash, WMV, ZYMV.

\section{Yozgat İli Çerezlik Kabak (Cucurbita pepo L.) Ekim Alanlarında Görülen Virüslerin Belirlenmesi}

ÖZET: Kabakgiller (Cucurbitaceae familyası), öncelikle tropik ve subtropikal bölgelerde dağılmış 119 cins ve 825 tür içerir. Kavun (Cucumis melo L.), salatalık (C. sativus L.), kabak (Cucurbita pepo L.) ve karpuz (Citrullus lanatus (Thunb) Matsum. \& Nakai) gibi kabakgil türleri dünya çapında en fazla yetiştirilen ve önemli sebze bitkileridir. Kabak çekirdekleri, Türkiye gibi bazı Akdeniz ülkelerinde ve Almanya, Macaristan, Avusturya ve Çin'de çerez olarak kullanılmaktadır. Yozgat ili çerezlik kabak ekim alanlarında yetiştirilen çerezlik kabaklarda (Cucurbita pepo L.) özellikle viral hastalıklar yıkıcı olmaktadır. Bu çalışmada, Yozgat çerezlik kabak ekim alanlarında sorun olan viral hastalıkların belirlenmesi amaçlanmıştır. 2017 yılında yapılan arazi çalışmalarında, mozaik, kıvırcıklaşma, beneklenme, iplik yapraklılık, bodurluk, yaprak ve meyvelerde şekil bozukluğu belirtileri gösteren bitkilerden toplam olarak 140 adet örnek toplanmıştır. Bu örneklerdeki virüsler, DAS-ELISA yöntemi ile belirlenmiştir. DAS-ELISA sonuçlarına göre; toplanan bitki örneklerinin \%84.28'inin Zucchini Sarı Mozaik Virüsü (ZYMV), Karpuz Mozaik Virüsü (WMV), Hıyar Mozaik Virüsü (CMV), Papaya Halkalı Leke Virüsü-karpuz straini (PRSV-W) ve Kabak Mozaik Virüsü (SqMV) ile bulaşık olduğu saptanmıştır. WMV, çalışmanın gerçekleştirildiği üretim alanlarında \%57.85 yaygınlık oranı ile en yaygın virüs olarak saptanmıştır. Bu virüsü ZYMV (53.57\%) takip etmiştir. Aynı zamanda, kabak örneklerinde karışık enfeksiyonlar da oldukça yaygın olarak gözlenmiştir. Özellikle, ZYMV+WMV karışık enfeksiyonları bunların arasında en yaygın olarak saptanmıştır. Laboratuar çalışmaları sonucunda, üretim alanlarından toplanan bitki örneklerinde Hıyar Yeşil Beneklilik Mozaik Virüsü (CGMMV)'ne rastlanmamıştır.

Keywords: Yozgat, DAS-ELISA, Çerezlik kabak, WMV, ZYMV

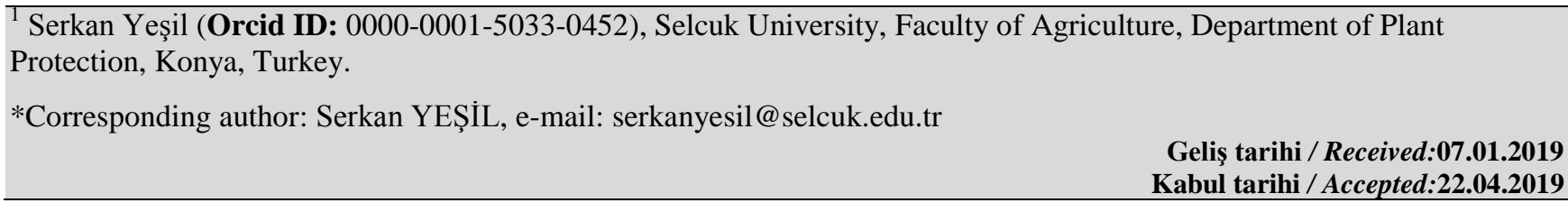




\section{INTRODUCTION}

Squash is grown for fresh consuming; also its seeds are consumed as a snack in Turkey like in Germany, some Mediterranean countries, Austria, China, and Hungary. Squash seeds are one of the most nutritionally rich vegetable byproducts out there, having a high content of unsaturated fat, protein, beta carotene, vitamin C, vitamin B1, fiber, iron, calcium, and potassium. These seeds were originally a main food for countries like China, United States, India, and Mexico and recently whole world has realized to the health benefits of these seeds. Although edible seed squash has been grown in Turkey for many years, there has been a rapid increase in the production area and quantity since 2004. As a result, in the year of 2017, edible seed squash production has reached 41.326 tons in about 65.000 ha. production area (TUIK, 2018). For squash growing, one of the most important problems is virus diseases. It's hard to estimates or calculates amount of yield losses in crops due to virus diseases. To the different calculations, $3-5 \%$ of overall cultivated vegetable crops are lost because of virus diseases, but the decreasing on the yield can be sometimes very high, where pest control is inadequate, particularly in developing countries (Caciagli, 2010). Viruses can cause important economic losses in the world for cucurbit growing. Indeed, on cucurbits, more than 39 different species have been determined as pathogen (Provvidenti, 1996; Lecoq, 2003). These pathogens cause complex and dynamically varying problems (Nameth et al., 1986). Edible seed squash is one of the most common vegetables grown in Yozgat province of Turkey. It occupied 900 ha in Yozgat in 2016, with a production of 76 tons (Anonymous, 2018). In previous reports, WMV, ZYMV, CMV, SqMV, PRSV-W, Cucurbit aphid borne yellows polerovirus (CABYV), Cucumber vein yellowing ipomovirus (CVYV), Tomato ring spot nepovirus (TRSV), Melon mosaic virus (MMV), and Tomato black ring nepovirus (TBRV) were determined on cucurbits from different parts of Turkey (Kurcman, 1977; Davis and Yilmaz, 1984; Nogay and Yorganc1, 1984; Erdiller and Ertunc, 1988; Yilmaz et al., 1991; Yilmaz et al., 1992; Fidan, 1995; Gümüs et al., 2001; Caglar et al., 2004).

ZYMV, WMV, and PRSV-W are typical members of Potyvirus genus (Potyviridae), so they have flexuous filamentous particles, and single stranded positive sense RNA genome. Potyviruses can be transmitted efficiently by mechanical inoculation and vector aphid species. ZYMV can be transmitted with seed to a low level, while PRSV-W and WMV are not transmitted with seeds (Lisa and Lecoq 1984, Purcifull et al. 1984a, Purcifull et al. 1984b). CMV is a polyhedral shaped virus that is member of the genus Cucumovirus in the Bromoviridae family and has a three-part genome consisting of ssRNA with positive polarity. This virus can be transmitted by seeds of some hosts, aphids and mechanically (Francki et al. 1979). SqMV, which has a positive sense ssRNA genome, belongs to the genus Comovirus (Secoviridae). The particle of the virus is hexagonal formed of isometric subunits and can be transmitted by insect vectors, seed and mechanically (Campbell 1971). CGMMV is a member of the Tobamovirus genus in the Virgaviridae family and is an important viral pathogen of cucurbit crops worldwide. The virus has rod shaped particles and single stranded positive sense RNA genome. CGMMV can be transmitted by foliage contact, handling of plants during cultivation, soil contamination, or through cucurbit seeds; no biological vector is known. (Dombrovsky et al. 2017).

In this study, one year of surveys were carried out to determine the incidence and distribution of viruses (CGMMV, CMV, PRSV- 
W, SqMV, WMV, ZYMV) infecting edible seed squash crops grown in Yozgat province.

\section{MATERIAL AND METHODS}

\section{Collecting of Virus Infected Squash Leaves}

Surveys were conducted by collecting symptomatic squash leaf samples from main squash growing fields in 5 different districts (Center, Şefaatli, Yenifakıl1, Sorgun, and Yerköy) of Yozgat province from July to September in 2017 (Table 1). In order to samples to represent Yozgat province, more than $\% 1$ of total edible seed squash growing areas (517da) of the province were surveyed. For this purpose, 28 edible seed squash fields were surveyed in the province. In these studies, the number of collected samples from each field was determined according to the surface area of the field. So that, at least 5 samples were collected from the fields which have up to 50 da and 8 samples were collected from the fields which have more than 50 da growing areas. The samples were collected from plants which showing virus-like symptoms as blisteringdistortion, mottling, vein clearing, mosaic, yellowing, shoe-string, or stunting and fruit discoloration and deformation. Five different leaves from each plant showing symptoms of virus diseases were taken as a sample. The samples were tested to determine for the infections of CMV, ZYMV, WMV, SqMV, CGMMV and PRSV-W. They were put in paper sacks, and kept in a deep-freezer $\left(-20^{\circ} \mathrm{C}\right)$ until test.

\section{Testing of Samples by Serologically}

In order to the virus infections (CGMMV, PRSV-W, CMV, SqMV, WMV, and ZYMV) on the squash leaf samples, DAS-ELISA (DoubleAntibody Sandwich Enzyme-Linked Immunosorbent Assay) test method was used (Clark and Adams, 1977). The antibodies were provided from commercial companies and used with respect to the instructions of them. Before the homogenization of the leaf samples, microplates were coated with virus IgG that were diluted in carbonate buffer $(\mathrm{pH} 9.6)$, and incubated for $4 \mathrm{~h}$ at $37^{\circ} \mathrm{C}$. The squash leaf samples were grinded in a mortar with the addition of the sample extraction phosphate buffer solution at a ratio of 1:10 (PBS, pH 7.4). After washing the microplates with washing buffer (PBST) thrice, the extracted samples were added to wells and incubated overnight in a refrigerator $\left(+4^{\circ} \mathrm{C}\right)$. Alkaline phosphatase (APP) conjugated antibody diluted in conjugate buffer ( $\mathrm{pH}$ 7.4) was added after washing the plates, and incubated for $4 \mathrm{~h}$ at $37^{\circ} \mathrm{C}$. Substrate buffer $(\mathrm{pH}$ 9.8) with Para-nitrophenylphosphate ( $P$-NPP) was added to each well and then, incubated for 30 to $90 \mathrm{~min}$. at dark and room temperature. Absorbance values were determined at $405 \mathrm{~nm}$ by Anthos 2010 Microplate Reader (Biochrom Ltd., Cambridge, UK). Test was assessed as positive when the average absorbance value of tested sample was bigger than two times of healthy (uninfected) control (Abou-Jawdah et al., 2000; Yesil and Ertunc, 2012).

Table 1. Surveyed districts and number of collected plant samples

\begin{tabular}{lccc}
\hline \multicolumn{1}{c}{ Districts } & Number of collected samples & Number of surveyed fields & Total areas of the fields (da) \\
\hline Yozgat (Center district) & $\mathbf{3 5}$ & $\mathbf{7}$ & $\mathbf{9 5}$ \\
Şefaatli & $\mathbf{5 0}$ & $\mathbf{1 0}$ & $\mathbf{2 8 2}$ \\
Yenifak1li & $\mathbf{2 0}$ & $\mathbf{4}$ & $\mathbf{7 0}$ \\
Sorgun & $\mathbf{2 0}$ & 4 & $\mathbf{4 3}$ \\
Yerköy & $\mathbf{1 5}$ & $\mathbf{3}$ & $\mathbf{2 7}$ \\
\hline \multicolumn{1}{c}{ Total } & $\mathbf{1 4 0}$ & $\mathbf{2 8}$ & $\mathbf{5 1 7}$ \\
\hline
\end{tabular}




\section{RESULTS AND DISCUSSION}

In this study, totally 140 edible seed squash leaf samples were tested by DAS-ELISA. The incidences of the different viruses which infect squash are given in Tables 2 and 3. They clearly showed that WMV and ZYMV are the most common squash viruses in the survey area. According to the results of the DAS-ELISA $84.28 \%$ of plant samples were infected with ZYMV, WMV, CMV, PRSV-W and SqMV (Fig.1). WMV was the most common virus in the research area with the ratio of $57.85 \%$. ZYMV was the second important virus disease in the survey area; it was detected on the samples at the ratio of $53.57 \%$. They are followed by CMV, SqMV and PRSV-W, 5.71, 5.71 and $2.85 \%$ in all tested samples, respectively. None of the tested samples was given positive reaction to CGMMV (Table 2). On 50 of all the samples were determined double virus infections. Mixed infections of WMV +
ZYMV were the most frequently detected ones in the samples with the ratio $27.85 \%$ (Table 3 ). Double infections with ZYMV + CMV, SqMV+WMV, PRSV-W+WMV, PRSV$\mathrm{W}+\mathrm{ZYMV}$ and CMV+WMV and were detected as $2.14,2.14,1.42,1.42$ and $0.71 \%$, respectively. Triple infections involving two combinations with ZYMV, WMV, CMV and SqMV were found in only four samples. While, two of them were infected by $\mathrm{ZYMV}+\mathrm{WMV}+\mathrm{SqMV}$, the other two were infected by ZYMV+WMV+CMV. Among the surveyed districts, the highest incidences of the viruses were detected in Yozgat-Center with the ratio of $88.57 \%$. WMV was the most commonly detected in samples from Yerköy (80\%), Sorgun $(60 \%)$ and Şefaatli $(60 \%)$. As for ZYMV, CMV, and SqMV were frequently detected in samples from Yerköy (73.33\%), Yenifakı1ı (10\%), and Yenifakılı (10\%), respectively.

Table 2. According to DAS-ELISA tests results, the number of single virus infections

\begin{tabular}{lcccccccc}
\hline District & No. Tested & Healty & CMV & SqMV & WMV & PRSV-W & ZYMV & CGMMV \\
\hline Yozgat (Center) & 35 & 4 & 1 & 2 & 8 & 0 & 10 & 0 \\
Sefaatli & 50 & 8 & 0 & 0 & 12 & 0 & 10 & 0 \\
Yenifakıll & 20 & 3 & 1 & 1 & 5 & 0 & 4 & 0 \\
Sorgun & 20 & 5 & 0 & 0 & 6 & 0 & 2 & 0 \\
Yerköy & 15 & 2 & 0 & 0 & 1 & 0 & 1 & 0 \\
\hline Total & 140 & $\mathbf{2 2}$ & $\mathbf{2}$ & $\mathbf{3}$ & $\mathbf{3 2}$ & $\mathbf{0}$ & $\mathbf{2 7}$ & $\mathbf{0}$ \\
\hline
\end{tabular}

Table 3. According to DAS-ELISA tests results, the number of double and multiple virus infections

\begin{tabular}{|c|c|c|c|c|c|c|c|}
\hline \multirow[b]{2}{*}{ District } & \multicolumn{6}{|c|}{ Double virus infections } & \multirow{2}{*}{$\begin{array}{c}\text { Triple } \\
\text { virus } \\
\text { infections }\end{array}$} \\
\hline & $\begin{array}{l}\text { ZYMV+ } \\
\text { WMV }\end{array}$ & $\begin{array}{l}\text { CMV+ } \\
\text { WMV }\end{array}$ & $\begin{array}{l}\text { CMV+ } \\
\text { ZYMV }\end{array}$ & $\begin{array}{l}\text { PRSV-W } \\
+W M V \\
\end{array}$ & $\begin{array}{l}\text { PRSV-W } \\
+ \text { ZYMV }\end{array}$ & $\begin{array}{l}\text { SqMV+ } \\
\text { WMV } \\
\end{array}$ & \\
\hline Yozgat (Center) & 8 & 0 & 1 & 0 & 0 & 0 & 1 \\
\hline Şefaatli & 14 & 1 & 1 & 0 & 1 & 1 & 2 \\
\hline Yenifakılı & 3 & 0 & 1 & 1 & 0 & 1 & 0 \\
\hline Sorgun & 5 & 0 & 0 & 0 & 1 & 1 & 0 \\
\hline Yerköy & 9 & 0 & 0 & 1 & 0 & 0 & 1 \\
\hline Total & 39 & 1 & 3 & 2 & 2 & 3 & 4 \\
\hline
\end{tabular}



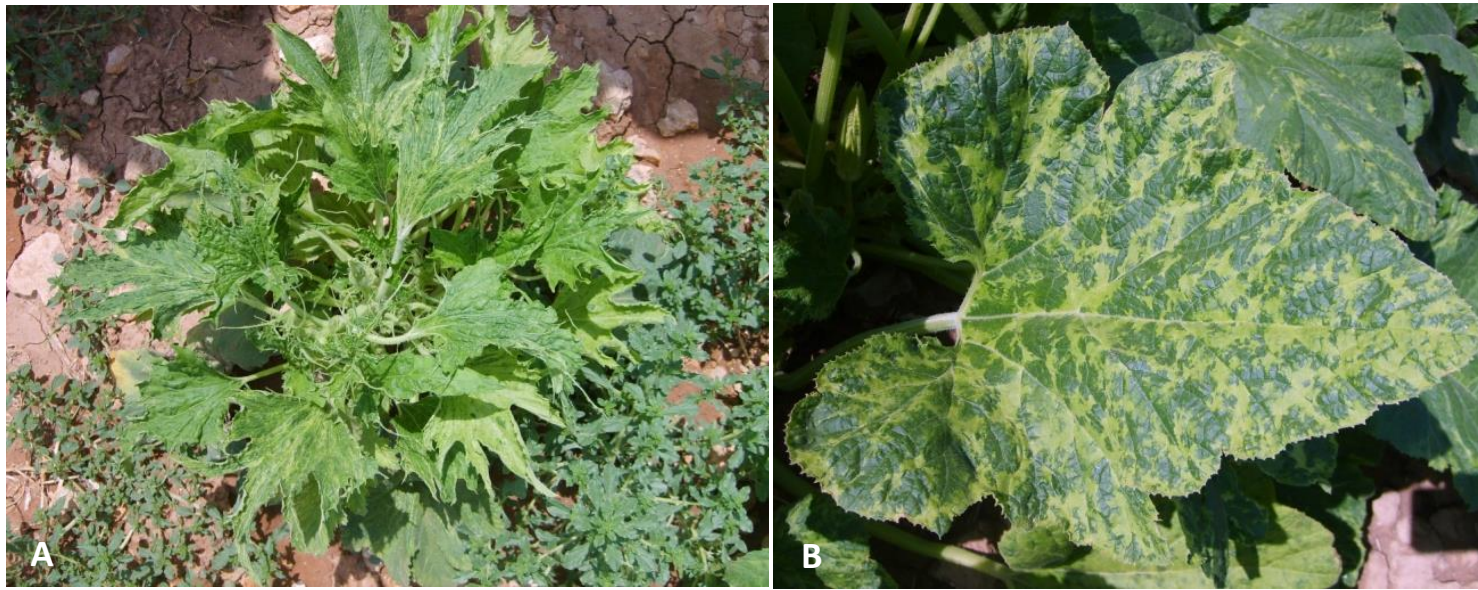

Figure 1. Virus diseases symptoms on edible seed squash plants. A: Severely leaf deformations and stunting caused by ZYMV. B: Mosaic and vein clearing symptoms because of ZYMV+WMV double infection.

Edible seed squash is economically important in Yozgat province, but have a high incidence of virus-like symptoms. During the surveys, different symptoms were observed such as leaf deformations (crinkle, blistering, shoestring, etc.), different chlorotic patterns on leaves (mosaic, ring spot, oak leaf, etc.), fruit deformations and growth reductions on squash plants. Also, symptoms of mineral deficiencies like growth reductions, wilting and yellowing were observed in some fields. The observed diseases symptoms in this study were similar to the symptoms previously reported from virusinfected cucurbits fields worldwide (Makkouk and Lesemann, 1980; Lecoq et al., 1981; Sammons et al., 1989; Provvidenti, 1996; LuisArteaga et al., 1998; Yuki et al., 2000; Davis et al., 2002; Massumi et al., 2007). The occurrence and incidence of viruses on cucurbit plants have been determined in different parts of Turkey. The infection of CMV, ZYMV, PRSV-W, WMV, SqMV, and ToMV has been reported in previous studies (Davis and Yilmaz, 1984; Nogay and Yorganc1, 1984; Erdiller and Ertunc, 1988; Yilmaz et al., 1991; Fidan, 1995; Caglar et al., 2004; Köklü and Yilmaz, 2006; Korkmaz et al., 2018). With this study, WMV and ZYMV were determined as the most widespread viruses in research area. Similarly, in a study which was carried out in different provinces of Turkey by Yilmaz et al. (1992), WMV and ZYMV were the most prevalent viruses among the tested viruses (ZYMV, WMV, CMV, CABYV and PRSV-W). Also, a survey was carried out in Konya province, 334 edible seed squash leaf samples were tested by DAS-ELISA, and ZYMV, WMV and CMV were determined on the samples with the ratios of $60.18 \%, 52.99 \%$ and $13.77 \%$, respectively (Yesil, 2014). The similar results were reported by the Ozaslan et al. (2006), they carried out a survey study to determine infections of cucurbit viruses in Gaziantep province of Turkey. They reported that ZYMV was the most common virus species on cucurbit plants and, also, the infections of CMV and Potato Potyvirus $Y$ (PVY) on cucurbits are common. To reveal viruses of cucurbits in Tokat province, a survey performed by Korkmaz et al. (2018). Totally 146 squash plant samples were tested by DAS-ELISA and they found WMV (38,35\%), ToMV (Tomato mosaic Tobamovirus) (22,53\%), ZYMV (26,71\%), CMV (13,01) and PRSV-W $(5,47 \%)$ infections on the samples. Also, they didn't determine any infection of TMV (Tobacco mosaic Tobamovirus), SqMV and PVY. 


\section{CONCLUSION}

The presences of PRSV-W, WMV, CMV, SqMV, and ZYMV on edible seed squash were detected in Yozgat. The results showed that one of the most important problems in squash growing in the province is virus infections. Because, during the survey studies, symptoms of virus diseases were observed almost each edible seed squash fields in the province. According to the results of this study, for reducing or eradication of virus diseases in squash production areas in the province and can be produced more yielded and more quality edible squash seeds the following suggestions must be regarded.

First of all, healthy, non-infected, pathogen-free and certified seed should be used.

For controlling virus diseases efficiently, it is very important to know about transmission ways and infection sources of the viruses. It's known that, except of SqMV, all viruses detected in our study were spread by mechanical inoculation and aphids (Hollings et al., 1981). Unfortunately, squash growers in the province neither know symptoms of virus diseases nor know transmission ways of the viruses from plant to plant. Therefore, they are not able to efficiently control virus diseases as they can't prevent the spread of viruses via vector aphid species.

Also, some of the common weed species in squash growing areas have a great importance in the epidemiology of virus diseases because they role as reservoir plants for some virus diseases (Zitter, 2002; Yesil and Ertunc, 2015). A research was performed by Yesil and Ertunc (2015) to determine of reservoir potentials of weeds which were grown in cucurbit fields in Konya, Karaman and Aksaray provinces of Turkey. According to the results of this research $50,6 \%$ of weed samples were infected with CMV, WMV, ZYMV, PRSV-W and SqMV. CMV was the most prevalent virus in the infected weed plants with the ratio of $36,5 \%$ and occurred in Amaranthus retroflexus (31\%), Chenopodium album (33,3\%), Convolvulus arvensis (42,9\%), Datura stramonium (66,6\%), Xanthium strumarium (42,9\%), Solanum nigrum (66,6\%), Agroptilon repense (100\%), Hibiscus trionum (50\%) and Rumex crispus (100\%) samples. CMV was followed by WMV $(22,3 \%)$, ZYMV (15,3\%), PRSV-W (2,3\%) and SqMV $(2,3 \%)$. WMV was detected in A. retroflexus (24,1\%), C. album (33,3\%), C. arvensis $(28,6 \%)$ and $S$. nigrum $(33,3 \%)$. As can be seen in this research, several weed species act as reservoir plants of some virus diseases in cucurbits fields. So, for preventing virus infection of cucurbits, weeds must be controlled.

As well in other plant crops production, in squash production cultural practices are very important. If all conditions which are necessary for growing healthy plant can be obtained, possibility of chance of phytopathological problems occurrence will be minimum. Therefore, cultural practices such as tilling, planting, manuring and irrigation should be done properly.

The plants showing virus diseases symptoms should be eradicated as soon as seen. Since, they act as infection sources for later infections.

\section{REFERENCES}

Abou-Jawdah Y, Sobh H, El-Zammar S, Fayyad A, Lecoq H, 2000. Incidence and management of virus diseases of cucurbits in Lebanon. Crop Protection, 19:217-224.

Anonymous, 2018. 2016-2017 y1lları Yozgat ili çerezlik kabak bitkileri üretim değerleri. Yozgat İl, Gida, Tarım ve Hayvancilık Müdürlüğü

Caciagli P, 2010. Vegetable Viruses. Pages 479-487 in: Desk Encyclopedia of Plant and Fungal Virology. Mahy, BWJ and Van Regenmortel, MHV eds. Academic Press, Linacre House, Jordan Hill, Oxford, OX2 8DP, UK. 
Caglar BK, Guldur ME, Yilmaz MA, 2004. First report of Squash mosaic virus in Turkey. Journal of Turkish Phytopathology, 86 (2), 177-180.

Campbell RN, 1971. Squash mosaic virus. Descriptions of Plant Viruses. [http://www.dpvweb.net/dpv/showdpv.php?dp vno=43] (Date of access: 20.03.2019).

Clark MF, Adams AN, 1977. Characteristics of the microplate method of enzyme-linked immunosorbent assay for the detection of plant viruses. Journal of General Virology, 34:475783.

Davis RF, Yilmaz MA, 1984. First Report of Zucchini Yellow Mosaic Virus on Watermelon and Squash in Turkey. Plant Disease, 68:537

Davis RI, Thomas JE, McMichael LA, Dietzgen RG, Callaghan B, James AP, Gunua TG, Rahamma $S$, 2002. Plant virus surveys on the island of New Guinea and adjacent regions of northern Australia. Australasian Plant Pathology, 31: 385-390.

Dombrovsky A, Tran-Nguyen LTT, Jones RAC, 2017. Cucumber green mottle mosaic virus: rapidly increasing global distribution, etiology, epidemiology, and management. Annu. Rev. Phytopathol. 55, 231-256.

Erdiller G, Ertunc F, 1988. Identification of muskmelon viruses in Ankara province. Journal of Turkish Phytopathology, 17:47-56.

Fidan U, 1995. Virus diseases of vegetables in greenhouses in Izmir and Mugla. Journal of Turkish Phytopathology, 24:7-14

Francki RIB, Mossop DW, Hatta T, 1979. Cucumber mosaic virus. Descriptions of Plant Viruses. [http://www.dpvweb.net/dpv/showdpv.php?dp vno=213]. (Date of access: 20.03.2019).

Gümüs M, Erkan S, Yorgancı U, Duman I, 2001. The investigation on the determination of viruses in the seeds of certain vegetables. Proceedings of the IX. Phytopathology Congress of Turkey. 38 September 2001, Tekirdağ, Turkey. 190-197.

Hollings M, Brunt AA, 1981. Potyviruses. In: Handbook of Plant virus Infections and Comparative Diagnosis. E. Kurstak, ed. Pages 731-807. Elsevier/North Holland Biomedical Press, Amsterdam, The Netherlands.
Korkmaz F, Topkaya Ş, Yanar Y, 2018. Tokat Kabakgil Üretim Alanlarında Enfeksiyon Oluşturan Virüslerin Belirlenmesi. Gaziosmanpaşa Bilimsel Araştırma Dergisi, 7 (2): 46-56.

Köklü G, Yilmaz O, 2006. Occurrence of cucurbit viruses on field-grown melon and watermelon in the Thrace region of Turkey. Phytoprotection, 87:123-130.

Kurcman S, 1977. Determination of virus diseases on cultural plants in Turkey. Journal of Turkish Phytopathology, 6:25-46.

Lecoq H, Pitrat M, Clement M, 1981. Identification et caractérisation d'un potyvirus provoquant la maladie du rabougrissement jaune du melon. Agronomie 1: 827-834.

Lecoq H, 2003. Cucurbits. Pages 665-687 in: Virus and Virus-like Diseases of Major Crops in Developing Countries. G. Loebenstein and G. Thottapilly, eds. Kluwer Academic Publishers, Dordrecht, The Netherlands

Lisa V, Lecoq H, 1984. Zucchini yellow mosaic virus. Descriptions of Plant viruses. [http://www.dpvweb .net/dpv/ showdpv.php?dpvno=282]. (Date of access: 20.03.2019).

Luis-Arteaga M, Alvarez JM, Alonso-Prados JL, Bernal JJ, Garcia-Arenal F, Lavina A, Batlle A, Moriones E, 1998. Occurrence, distribution, and relative incidence of mosaic viruses infecting field-grown melon in Spain. Plant Disease, 82: 979-982.

Makkouk K.M, Lesemann DE, 1980. A severe mosaic of cucumbers in Lebanon caused by Watermelon mosaic virus-1. Plant Disease, 64: 799-801.

Massumi H, Samei A, Pour AH, Shaabanian M, Rahimian H, 2007. Occurrence, Distrubution, and Relative Incidence of Seven Viruses Infecting Greenhouse-Grown Cucurbits in Iran. Plant Disease, 91:159-163.

Nameth ST, Dodds JA, Paulus AO, Laemmlen FF, 1986. Cucurbit viruses of California: an everchanging problem. Plant Disease, 70: 8-11. 
Nogay A, Yorganc1 U, 1984. Investigations on the identification, seed transmission and host range of viruses infecting the culture plants in the Cucurbitaceae in Marmara region. 1. The identification of viruses infecting cucurbits in Marmara region. Journal of Turkish Phytopathology, 13:9-28

Ozaslan M, Aytekin T, Bas B, Kilic H, Afacan ID, Dag DS, 2006 Virus Diseases of Cucurbits in Gaziantep, Turkey. The Plant Pathology Journal 5, 24-27.

Provvidenti R, 1996. Diseases caused by viruses. In: Zitter TA, Hopkins DL, Thomas CE (eds), Compendium of Cucurbit Diseases, Minnesota, USA, APS Press, pp. 37-45.

Purcifull D, Edwardson J, Hiebert E, Gonsalves D, 1984a. Papaya ringspot virus. Descriptions of Plant Viruses. [http://www.dpvweb.net/dpv/showdpv.php?d pvno $=292$ ]. (Date of access: 20.03.2019).

Purcifull D, Hiebert E, Edwardson J, 1984b. Watermelon mosaic virus 2. Descriptions of Plant Viruses. [http://www.dpvweb.net/dpv/showdpv.php?d pvno=293]. (Date of access: 20.03.2019).

Sammons B, Barnett OW, Davis RF, Mizuki MK, 1989. A survey of viruses infecting yellow summer squash in South Carolina. Plant Dis. 73: 401-404.

TUIK, 2018. Amount of crop and planting areas of edible seed squash of Turkey in 2018. www.tuik.gov.tr (Date of access: 28.09.2018)

Yesil S, Ertunc F, 2012. Virus Diseases of Cucurbits in Konya Province. In: Proceedings of the Xth EUCARPIA meeting on genetics and breeding of Cucurbitaceae (eds. Sari, Solmaz and Aras), October, 15-18th, 2012, Antalya, Turkey, pp. 791-796.

Yesil S, 2014. Virus Diseases of Edible Seed Squash (Cucurbita pepo L.) in Konya Province. In: Book of Proceedings Fifth International Scientific Agricultural Symposium (AGROSYM-2014), October, 23-26th, 2014, Jahorina, Sarajevo, Bosnia-Herzegovina, 226 p. ISBN: 978-99955-751-9-9
Yesil, S, Ertunc F, 2015. Reservoir Weeds of Cucurbit Viruses in Central Anatolia. In:. Proceedings of the International Congress on Applied Biological Sciences (ICABS-2015). September 16-20, 2015, Skopje, Macedonia, $36 \mathrm{p}$.

Yilmaz MA Ozaslan M, Baloğlu S, 1991. Çukurova bölgesinde yetistiriciligi yapılan kavun, karpuz ve hıyar bitkilerine zararlı yeni bir virüs hastalığı. Turkiye VI. Fitopatoloji Kongresi. İzmir-Turkiye, 387-391.

Yilmaz MA, Lecoq H, Abak K, Baloglu S, Sar1 N, 1992. Türkiye'de kabakgil sebze türlerinde zarar yapan virüsler. Türkiye I. Ulusal Bahçe Bitkileri Kongresi, İzmir, Bildiriler kitabı, 439-442.

Yilmaz MA, Baloğlu S, Ozaslan M, Güldür ME, 1995. GAP Bölgesinde kültür bitkilerinde belirlenen virüsler. GAP Bölgesi Bitki Koruma Sorunları ve Çözüm Önerileri Sempozyumu. Şanlıurfa-Turkiye, 241-250.

Yuki VA, Rezende JAM, Kitajima EW, Barroso PAV, Kuniyuki H, Groppo GA, Pavan MA, 2000. Occurrence, distribution, and relative incidence of five viruses infecting cucurbits in the state of Sao Paulo, Brazil. Plant Disease, 84: 516-520.

Zitter AT, 2002. A checklist of major weeds and crops as natural hosts for plant viruses in the Northeast. Department of Plant Pathology, Cornell University, Ithaca, NY, New York. (Date of access: 20.03.2019) http://vegetablemdonline.ppath.cornell.edu/Ta bles/ WeedHostTable.html\#Keys. 